\title{
Dilemma in Day Care: The Virtues of Administrative Accommodation
}

\author{
Greg J. Matis $\dagger$
}

\section{INTRODUCTION}

The religion clauses of the First Amendment share the same fundamental purpose: to prevent extensive government involvement in matters of religion. ${ }^{1}$ In simplified terms, one can say that the Establishment Clause forbids government prescription of religion, and that the Free Exercise Clause forbids its proscription. Thomas Jefferson conceived the clauses as erecting "a wall of separation between church and state,"2 but this "separationist" conception-whatever its theoretical merits-offers little practical guidance in the modern state, where government affects a much wider range of private activity than at the time of the founding. ${ }^{3}$ Jefferson's separation, "far from being a 'wall,' is a blurred, indistinct, and variable barrier." With a strict separation of church $^{5}$ and state unlikely or impossible, government neutrality toward religion emerges as an alternative formulation of the clauses' objective. ${ }^{6}$ In

+ B.A. 1987, Brigham Young University; J.D. Candidate 1990, The University of Chicago.

${ }^{2}$ The clauses provide: "Congress shall make no law respecting an establishment of religion, or prohibiting the free exercise thereof ...." US Const, Amend I.

${ }^{2}$ Letter to the Committee of the Danbury Baptist Association (Jan 1, 1802), in Adrienne Koch and William Peden, eds, The Life and Selected Writings of Thomas Jefferson 332 (Random House, 1972). See also Justice Rehnquist's dissent in Wallace v Jaffree, 472 US 38, 91-114 (1985) for a criticism of Jefferson's metaphor.

${ }^{3}$ The original amendment did not apply to the states, and the framers did not intend them to be similarly constrained. Though the clauses were the evolutionary pinnacle of separationist efforts in Virginia, see Anson P. Stokes and Leo Pfeffer, Church and State in the United States 65-71 (Greenwood Press, 1964), many of the other states openly sponsored churches. Id at 78-82; Wallace, 472 US at 99 n 4 (Rehnquist dissenting); McDaniel v Paty, 435 US 618,623 (1978). For a complete discussion of the religion clauses' historical context, see Thomas J. Curry, The First Freedoms (Oxford, 1986). As the Fourteenth Amendment significantly expanded the governmental action subject to the reach of the religion clauses, it limited the possibility of separation.

4 Lemon v Kurtzman, 403 US 602, 614 (1971).

s This Comment uses the term "church" interchangeably with "religious institution." Thus, "church-sponsored" or "church-operated" day care encompasses religiously affiliated providers of all denominations.

- Walz v Tax Commission, 397 US 664, 668-69 (1970); Committee for Public Education 
Justice Black's words, the government should not "pass laws which aid one religion, aid all religions, or prefer one religion over another." And, to paraphrase his words and apply them to the free exercise side of the neutrality equation, neither should the government pass laws that hinder one religion, hinder all religions, or disadvantage one religion in comparison to another. ${ }^{8}$ But neutrality, like strict separation, must often remain an ideal.

Consider the quest for "neutrality" in the context of a religious institution rendering a secular, regulated service such as day care. At first blush, neutrality suggests that the state should expose a church-sponsored day care provider to the same benefits, burdens, and regulations as its non-religious counterparts. But treating church-sponsored day care providers like non-religious institutions could create excessive burdens on the free exercise of religion. Conversely, providing extensive exemptions could disadvantage secular day care providers, with whom the church-sponsored providers compete. Neutrality is therefore an elusive end, the search for which is circumscribed by threats of both the establishment of religion and infringement on free exercise.

Thus, despite their shared purpose, the religion clauses stand in tension and present those who govern with a dilemma: whether to exempt church-sponsored day care centers from state regulation. This Comment examines the constitutional dilemma in day care. The first section describes the basic conflict, reviewing the nature and extent of church involvement in day care and cataloguing the various forms of state regulation. Section II considers the Free Exercise Clause challenges to regulation of church-sponsored day care. Section III considers the Establishment Clause challenges, focusing on the controversy surrounding exemptions for church-sponsored day care in light of the Supreme Court's recent decision in Corporation of Presiding Bishop v Amos. ${ }^{9}$ Following the contours of this case, the fourth section proposes an approach to the regulation of day care that balances the demands of the religion clauses. The Comment concludes that those engaged in the delicate process of accommodating the free exercise concerns of

\footnotetext{
$v$ Nyquist, 413 US 756, 792-93 (1973).

7 Everson v Board of Education, 330 US 1, 15 (1947).

8 As one would expect, there are other conceptions of neutrality. Professor Kurland defines neutrality as barring any religious classifications. Philip B. Kurland, Of Church and State and the Supreme Court, 29 U Chi L Rev 1 (1961). For an economic definition of neutrality, see Michael W. McConnell and Richard A. Posner, An Economic Approach to Issues of Religious Freedom, 56 U Chi L Rev 1 (1989).

๑ 483 US 327 (1987).
} 
church-sponsored day care providers should focus on specific regulations and specific objections. Administrative tailoring of the regulatory process to suit individual church-sponsored providers is the least restrictive means of accommodating their free exercise concerns while avoiding an impermissible establishment of religion.

\section{The Day Care Dilemma: Church Involvement and State REGULATION}

In First Amendment jurisprudence, "church" and "state" are often treated as competing monoliths, each with its own well-defined complement of interests and characteristics. A large part of the day care dilemma is the absence of any such categorical coherence. Churches provide day care services in widely different forms for vastly different motives. And although all states' day care licensing regulations ostensibly share a common purpose-protecting children's health and safety-no two states have chosen the same means to that end. The various state regulatory schemes have as many differences as similarities. This section provides a brief introduction to the complex nature of church and state participation in day care.

\section{A. Church Involvement}

Churches have long played a significant role in nurturing and educating the young. Although comprehensive nationwide data on the extent and nature of church participation in day care is predictably missing, an ambitious study by the ecumenical National Council of Churches ("NCC") sheds some light on the contours of church involvement in day care. ${ }^{10}$ The NCC canvassed over 14,000 church-housed day care programs and concluded that "churchhoused programs probably constitute the largest group of day care providers in the nation."11 Yet the study also revealed rich diversity in the forms and purposes of church programs.

${ }^{20}$ This Child Day Care Project is described and documented in Eileen W. Lindner, et al, When Churches Mind the Children: A Study of Day Care in Local Parishes (High/ Scope Press, 1983). The NCC is comprised of thirty-two Protestant, Anglican, and Orthodox denominations representing over forty million Americans. While the study's results cannot be extrapolated to all American churches, the NCC does represent a significant portion of them, and its findings immeasurably increase the extant national information about church involvement in child care.

11 Id at 12. The NCC estimated "that the nation's churches, collectively, house part- or full-day care for several million children." Id at 73 . 
Significantly, forty-four percent of the study's church-housed programs were only that: church-housed, not church-operated. ${ }^{12}$ The churches' involvement in these programs is limited to that of a landlord, albeit a rather generous one. ${ }^{13}$ For day care tenants, the appeal is fairly obvious: in addition to subsidization or waiver of rent, utilities, and maintenance costs, church day care tenants benefit from convenient locations, spaces that are often already designed for small children, and most importantly, the tax-exempt status of their gracious hosts. ${ }^{14}$ For their part, the host churches view the arrangement as an opportunity to contribute their facilities to a worthy cause. ${ }^{15}$

The other fifty-six percent of the study's programs were housed and operated by the host churches. The churches typically view day care as an aspect of their particular ministries: some host churches are simply trying to provide a valuable community service, or to meet the day care needs of their congregations' families; others act out of evangelism and a desire to promote Christian education. $^{16}$ Yet despite these religious goals, almost none of the church-operated programs restrict participation to members of their own congregations, ${ }^{17}$ and "symbols, practices, and teachings commonly viewed as 'religious' are conspicuously absent from most church-operated programs." 18 Church-operated day care centers are, however, "much more likely to give some consideration to religious beliefs when hiring staff" than their independently-operated counterparts. ${ }^{19}$ Finally, and perhaps most surprising, the study found that the great majority of church-housed day care centers obtained state licenses for either part or all of their day care programs, even when not required to do so. ${ }^{20}$

12 Id at 34.

${ }^{13}$ Nearly half of the independently operated day care centers paid only token rent ( $\$ 100$ or less) or no rent at all, and eighty-seven percent received some sort of subsidy from the host church. Id at 133-34.

14 Id at 19.

15 Id at $20-21$.

${ }^{16}$ Id.

17 Ninety-nine percent of the programs in the study were open to all members of their respective communities. Id at 26 .

${ }^{18}$ Id at 75. The study noted that church-operated centers are "somewhat more likely to be concerned with the 'spiritual development of the child' than independently operated centers, but only a small minority of the centers consider this a high priority goal."

18 Id.

${ }^{20}$ The study claimed "unanimous insistence" among the church-operated program directors interviewed that church-housed programs should "be held accountable for meeting licensing requirements." Id at 105. Eighty-four percent of the day care centers licensed at least part of their operations. Id at 58 . 
This snapshot of church involvement in day care provides a general picture that is too often obscured by the specific, high-profile controversies considered in this Comment. If the NCC study shows anything, it is that a substantial proportion of church-sponsored day care providers share the same standards and strive for the same goals as secular day care providers.

\section{B. State Regulation}

The recent large-scale movement of women into the workforce fueled an explosion in the demand for day care. ${ }^{21}$ As day care services multiplied, so did the states' incentives to ensure their quality. ${ }^{22}$ Except for the common objective of protecting children's health, safety, and well-being, however, the resulting regulations are far from uniform. A description of the range of existing approaches and the most common features among state regulatory schemes follows.

\section{State licensing requirements.}

State legislatures typically lay the foundations for the regulation of day care providers by establishing broad areas of concern or a set of minimum standards, and then delegating the bulk of specific rulemaking to a state administrative agency. The agency, typically the department of human services or its equivalent, is authorized to establish, monitor, and enforce a comprehensive licensing program. $^{23}$

This legislative authorization is often limited to licensing requirements protecting children's "health and safety," a phrase with remarkably elastic parameters. In their narrowest sense, "health and safety" provisions are the basic fire, construction, and building code regulations that apply to all public structures, including places of worship; all the states regulate these basic physical aspects of day care facilities in the same manner as they regu-

21 The percentage of working mothers with children under six years of age almost doubled from thirty percent in 1970 to fifty-seven percent in 1987. U.S. Census Bureau data, cited in Pat Wingert and Barbara Kantrowitz, The Day Care Generation, in The TwentyFirst Century Family, Newsweek Special Issue 87 (Winter/Spring 1990).

${ }^{22}$ Rapid, unregulated growth led to highly publicized examples of day care gone awry and was often seen as a state crisis. See Fla Stat Ann $\S 402.301$ Preamble (West 1986); and Tex House Comm on Hum Res, 63d Tex Leg, Report on the Interim Study on Child-Caring in Texas 7 (November 12, 1974). All fifty states and the District of Columbia now regulate day care services.

${ }^{23}$ See, for example, Ariz Rev Stat Ann $\S 36-883$ (West 1982 \& Supp 1989); NJ Stat Ann $\S 30:$ 5B-5(a) (West 1981 \& Supp 1989). 
late public buildings. ${ }^{24}$ But in practice, protecting "health and safety" often translates into regulating a much wider range of attributes. Among the areas most frequently regulated are child/staff ratios, personnel qualifications, and policies regarding nutrition, discipline, record-keeping, and parental participation. ${ }^{25}$

However broad their interpretations of "health and safety," the states are nearly uniform in leaving certain areas alone: none of the states has used this authority to regulate the curriculum. In fact, most state authorizing statutes explicitly forbid regulation of educational content. ${ }^{26}$ And many specifically note the intention to safeguard freedom of religious instruction and training. ${ }^{27}$

After the state agency promulgates licensure requirements, day care providers typically apply for a license by demonstrating compliance and sometimes paying a fee. Before receiving a license, providers may also be subject to on-site inspection for verification of compliance. The possibility of inspections usually continues after providers are licensed, and licenses often must be posted in a visible location in the center. ${ }^{28}$ The requirements are usually enforced through criminal and civil penalties, including license revocation. ${ }^{29}$

2. Exemption from licensing requirements.

An increasing number of states provide special legislative exemptions from licensing requirements for church-sponsored day care providers, usually substituting secondary systems of regulation. Often described as "registration," these alternatives to licensure vary greatly, but their chief purpose is to accommodate the unique free exercise interests of church-sponsored providers. ${ }^{30}$

${ }^{24}$ See, for example, NJ Stat Ann $\S 30: 5 B-5(e)$; La Rev Stat Ann $§ 46: 1413 B$ (West 1982 \& Supp 1990).

${ }^{25}$ See, for example, Ill Ann Stat ch 23, § 2217(a) (Smith-Hurd 1988 \& Supp 1989).

${ }^{26}$ California's statute is representative: "licensing reviews of a day care center shall be limited to health and safety considerations and shall not include any reviews of the content of any educational or training program of the facility." Cal Health \& Safety Code $\S$ 1597.05(a) (West 1979 \& Supp 1990). See also Ga Code Ann § 49-5-12(b)(6) (Michie 1986 \& Supp 1989).

${ }^{27}$ Idaho's statute declares: "Nothing in this chapter shall be construed to limit or restrict the teaching of religious doctrines, values, or tenets in a facility licensed under the provisions of this chapter." Idaho Code $\S 39-1103$ (1985 \& Supp 1989). See also Tex Hum Res Code Ann $\$ 42.001$ (Vernon 1980).

${ }^{28}$ See, for example, La Rev Stat Ann § 46:1408C.

${ }^{29}$ See Ga Code Ann $\S 49-5-12(r-t)$ for typical enforcement provisions.

${ }^{30}$ See North Valley Baptist Church v McMahon, 696 F Supp 518, $528 \mathrm{nn} 18,19$ (E D Cal 1988), and accompanying text for a general discussion of registration provisions. 
Under registration, church-sponsored providers are often technically subject to many of the same regulations as secular providers, but compliance is'more voluntary, with decreased monitoring and less enforcement by the state. Enforcement is often relegated to consumer-initiated judicial procedures instead of state-initiated administrative oversight. ${ }^{31}$

States providing broad legislative exemptions often take precautionary measures. For example, exempt centers are still subject to inspection to ensure compliance with basic health and safety standards (narrowly construed). ${ }^{32}$ In addition, exempt centers may be required to disclose their "unlicensed" status in any advertising. ${ }^{33}$ Some states require parents' informed consent to certain policies and procedures, including, for example, the center's discipline practices. ${ }^{34}$

Exemptions may also be granted by other branches of government. Because the bulk of regulation is often left in the hands of the implementing agency, many exemptions are effected at the administrative level, where rulemaking, interpretation, and enforcement provide opportunities to exempt. ${ }^{35}$ In addition, the courts may grant exemptions when reviewing legislative and administrative actions involving church-sponsored day care. ${ }^{36}$

31 The only enforcement mechanism in Alabama, for example, is the rather unimpressive statutory reminder that district attorneys have discretion to investigate any allegations against exempt centers. Ala Code $\S 38-7-3$ (1975 \& Supp 1989). This is not to say that all registration statutes lack teeth. Consider Arkansas, whose version of registration is licensing by another name. The only significant difference is that church-sponsored day care providers "voluntarily" submit to regulation. They are still required to substantially comply with day care regulations and are subject to state inspection for verification. 1987 Ark Acts 20-78221. The scheme is considered in further detail below in the discussion of Arkansas Day Care Ass'n, Inc. $v$ Clinton, 577 F Supp 388 (E D Ark 1983) in the text at notes 95-104.

${ }^{32}$ See, for example, Ala Code § 38-7-3; Ind Code Ann § 12-3-2-12.7(e) (West 1982 \& Supp 1989).

${ }^{33}$ Indiana requires each exempt center to refer to itself in advertising as a day care "ministry" and "clearly state in all of its paid promotional advertising that the day care ministry is providing day care as an extension of its church or religious ministry." Ind Code Ann \$ 12-3-2-12.7(i).

34 Alabama requires disclosure of "staff qualifications; pupil-staff ratio; discipline policies; type of curriculum used in the learning program; the religious teachings to be given each child; and the type of lunch program available." Parents and a representative from the sponsoring church board must sign a prescribed affidavit testifying to the disclosure and consent before any child may be enrolled and once every year thereafter. Ala Code § 38-7-3.

35 Some state statutes explicitly provide for administrative latitude in granting exemptions. Louisiana, for example, grants the Department of Health and Human Resources the authority to grant exemptions if compliance is financially "impractical" or if the facility is "meeting or exceeding the intent of a standard or regulation." La Rev Stat Ann $§ 46: 1409 \mathrm{E}$ and 46:1413I-J.

${ }^{36}$ See Section III. 
3. Subsidization.

Another form of more direct government involvement merits brief mention. The federal government has long provided limited assistance to day care efforts, ${ }^{37}$ and encouraged states to follow suit. Burgeoning demand has forced both the federal and state governments to consider substantial increases in the subsidization of day care. Despite intense controversy, it is likely the 101st Congress will pass some version of increased day care subsidies during the second session..$^{38}$ Part of the concern, of course, is establishment. Because subsidization invokes an entirely different Establishment Clause analysis than licensing requirements, particularly with respect to content restrictions, ${ }^{39}$ this Comment assumes no state subsidization and does not delve into its implications.

\section{The Free Exercise Clause and Challenges to Regulation}

A. The Compelling Interest Test ${ }^{40}$

The Supreme Court has described the Free Exercise Clause as "embrac[ing] two concepts-freedom to believe and freedom to act. The first is absolute but, in the nature of things, the second cannot be. Conduct remains subject to regulation for the protection of society." "41 To determine if a regulation impermissibly inter-

${ }^{37}$ The federal government has provided: direct care, such as Head Start, 42 USC § 9831 et seq (1988): "demand subsidies," such as limited tax deductions and credits, 26 USC $\S 44(\mathrm{~A})$ (1988); and auxiliary services to day care providers. See Rochelle Beck, Beyond the Stalemate in Child Care Public Policy, in Edward F. Zigler and Edmund W. Gordon, eds, Day Care: Scientific and Social Policy Issues 317 (Auburn House, 1982); and Sharon L. Kagan and Theresa Glennon, Considering Proprietary Child Care, in Zigler and Gordon, Day Care 403.

${ }^{38}$ Elaine S. Povich, Bitter Fight Expected Over Child-Care Bill, Chicago Tribune § 1 at 5 (January 22, 1990).

${ }^{39}$ A large part of the controversy over federal legislation centers on just this point. See Joseph L. Conn, Day Care Debacle: Senate Adopts Voucher Plan for Sectarian Child Care and Instruction. Will the House Follow Suit?, Church \& State 4 (Sept 1989).

10 Days before this Comment went to press, the Supreme Court released its decision in Employment Div., Dept. of Human Resources of Oregon v Smith, 1990 US LEXIS 2021 (April 17, 1990) ("Smith II"). Quite unexpectedly, and in the face of vigorous dissent, a 5-4 majority drastically narrowed the application of the compelling interest test. In Smith II, the Court held that the Free Exercise Clause permits a state to prohibit sacramental peyote use and thus to deny unemployment benefits to persons discharged for such use. Interpreted broadly, the Smith II ruling suggests that generally applicable day care regulations are no longer subject to the compelling interest test and will rarely, if ever, violate the Free Exercise Clause. It remains to be seen, of course, how Smith II will actually be applied in the day care or any other context.

1 Cantwell v Connecticut, 310 US 296, 303-04 (1940). The belief-conduct distinction originated in Reynolds v United States, 98 US 145 (1878), where the Court upheld a Mormon's conviction for polygamy. 
feres with religious conduct, the Supreme Court applies a balancing approach often called the compelling interest test. ${ }^{42}$ Under the test, the plaintiff must show that the regulation at issue burdens conduct motivated by a sincerely held religious belief. ${ }^{43}$ The burden need not be direct or explicit in the regulation. ${ }^{44}$ If the plaintiff establishes a free exercise burden, the regulation will only be upheld if the state can demonstrate that it has a compelling interest in the regulation ${ }^{45}$ and the regulation is the least restrictive means of serving the state's interest. ${ }^{46}$

The least restrictive means requirement focuses the free exercise inquiry. In the day care context, for example, it would be easy

12 The test emerged from Braunfeld $v$ Brown, 366 US 599 (1961), and Sherbert $v$ Verner, 374 US 398 (1963). For a more recent application, see Hobbie v Unemployment Appeals Comm'n, 480 US 136 (1987).

${ }^{13}$ Only the sincerity of the belief-not its truth-is at issue. United States $v$ Ballard, 322 US 78, 86-87 (1944). It does not matter that other adherents to the same religion do not hold the particular belief. See Thomas v Review Board, 450 US 707, 715-16 (1981) ("the judicial process is singularly ill equipped to resolve such differences" and "[c]ourts are not arbiters of scriptural interpretation"); and United States v Lee, 455 US 252, 257 (1982) (the Court declined to decide whether the Old Order Amish plaintiff's belief was "the proper interpretation of the Amish faith"). And the belief need not be "logical, consistent, or comprehensible to others in order to merit First Amendment protection." Thomas, 450 US at 714. It must, however, be "rooted in religion" and not merely the plaintiff's "personal philosophical choice." Id at 713-14. For a recent critique of the Court's approach to the burden inquiry, see Ira C. Lupu, Where Rights Begin: The Problem of Burdens on the Free Exercise of Religion, 102 Harv L Rev 933 (1989).

14 "Where the state conditions receipt of an important benefit upon conduct proscribed by a religious faith, or where it denies such a benefit because of conduct mandated by religious belief, thereby putting substantial pressure on an adherent to modify his behavior and to violate his beliefs, a burden upon religion exists. While the compulsion may be indirect, the infringement upon free exercise is nonetheless substantial." Thomas, 450 US at 717-18. See also Everson v Board of Education, 330 US 1, 16 (1947). But see Braunfeld, 366 US at 606-07 "'To strike down, without the most critical scrutiny, legislation which imposes only an indirect burden on the exercise of religion, i.e., legislation which does not make unlawful the religious practice itself, would radically restrict the operating latitude of the legislature.").

45 Sherbert defined this "paramount" interest as involving "some substantial threat to public safety, peace or order." 374 US at 403,407 . Later cases reveal that the standard for "compelling" is dependent on the implicit balancing of interests that the test entails. The Thomas Court, for example, reiterated that "'only those interests of the highest order' can overbalance legitimate claims to the free exercise of religion." 450 US at 718 (emphasis added), quoting Wisconsin v Yoder, 406 US 205, 215 (1972). Interests that the Court has found sufficiently compelling include: national security, Gillette v United States, 401 US 437 (1971); the social security system, Lee, 455 US at 258 ; the prevention of racial discrimination, Bob Jones University v United States, 461 US 574 (1983); the prevention of polygamy, Reynolds v United States, 98 US 145 (1878); and the protection of children, Prince $v$ Massachusetts, 321 US 158, 167 (1944) (upholding child labor law that prevented Jehovah's Witness child from proselytizing).

46 Thomas, 450 US at 718. This requirement often remains implicit. See Lee, 455 US at 258-59. 
to declare the ultimate importance of either side's interest: the state seeks to protect children's health and safety; ${ }^{47}$ church-sponsored day care providers seek to preserve their religious freedom. ${ }^{48}$ The least restrictive means requirement assures that the issue in an individual case will be the degree to which a particular state requirement infringes upon the specific religious beliefs or practices of a church-sponsored day care provider, and the degree to which the state's interest would be jeopardized by granting that provider an exemption. ${ }^{49}$ Thus, whether free exercise is infringed depends on specific regulatory provisions, the nature of the religious objections to them, and the possibilities for satisfying the state's interest in less intrusive ways.

\section{B. Free Exercise Objections}

Day care providers may raise either specific or general objections to a state's day care regulations. Specific objections target individual licensing requirements, with the church-sponsored day care provider claiming that one or several requirements burden particular aspects of its religious exercise. General objections target regulation itself: the church-sponsored day care provider claims that its service is a religious exercise, and protests any state restrictions or mandates as a burden on free exercise. ${ }^{50}$

${ }^{47}$ No court reviewing child care licensing provisions has found this compelling state interest lacking. In large part, the Supreme Court assured this result with its declaration that "[i]t is too late now to doubt that legislation appropriately designed to reach such evils [affecting children] is within the state's police power, whether against the parent's claim to control of the child or one that religious scruples dictate contrary action." Prince, 321 US at 168-69.

${ }^{48}$ Only rarely do courts find that church-sponsored day care plaintiffs failed to establish religious burden. See North Valley Baptist Church v McMahon, 696 F Supp 518 (E D Cal 1988), discussed below at note 62 .

${ }^{49}$ See Yoder, 406 US at 236 ("weighing the minimal difference between what the State would require and what the Amish already accept, it was incumbent on the State to show with more particularity how its admittedly strong interest in compulsory education would be adversely affected by granting an exemption to the Amish"); and McConnell and Posner, 56 U Chi L Rev at 53 (cited in note 8).

${ }^{\text {so }}$ A Maryland legislator protested that Maryland's licensing statute means that permission to operate a ministry "comes from [Maryland Governor] Don Schaefer and not from God." Churches Unite Against State Licensing of Church Ministries, Christian News (December 19, 1988). Some of the church-sponsored day care providers that assert general objections do not object to the particular licensing requirements, and in fact might be in full compliance. State v Corpus Christi People's Baptist Church, 683 SW2d 692, 694 (Tex 1984). Others assert specific objections as well. See North Valley Baptist Church v McMahon, 696 F Supp 518, 524 (E D Cal 1988). 


\section{General objections}

When a party objects to the whole notion of government involvement in day care regulation, the emphasis placed in the balancing process upon least restrictive means is likely to doom the objection. For example, in North Valley Baptist Church v McMahon, North Valley claimed that submitting to licensure constituted "a clear violation of the Lordship of the Lord Jesus Christ" over the church. ${ }^{11}$ In applying the compelling state interest test to the claim, the federal district court found that the state regulation burdened North Valley's religious expression but that the scheme furthered the state's compelling interest in protecting the health and safety of children in day care. The case thus turned on "the extent to which recognition of an exemption from the licensure requirement would impede the objective sought to be advanced by the state." ${ }_{22}$ After considering the facts, the court found that the state had no effective, less restrictive alternative to advance its compelling interest; some form of regulation was necessary to protect the children's health and safety. ${ }^{53}$

\section{Specific objections.}

Specific objections to licensing requirements present a variety of possible outcomes under the compelling interest test. The strength of a state's interest in the particular regulatory standard is a critical variable. Some standards, particularly those requiring compliance with seemingly insignificant statutory details, ${ }^{54}$ represent slight state interests. For example, Texas's regulatory standards require, among other things, that children participate in community activities, that clothing provided for children meet certain community standards, and that children not be required to perform at public gatherings. ${ }^{\mathrm{SS}}$ Though one can posit a number of

\$1 696 F Supp at 522. North Valley objected to any form of regulation that required state approval (even most registration plans would fall victim to a challenge this broad). Id at 530 .

52 Id at 527.

s3 Id at 529-530. Courts in both Texas and Michigan have rejected similar general objections to regulation. See People's Baptist, $683 \mathrm{SW} 2 \mathrm{~d}$ at 696; and Dept of Social Services $v$ Emmanuel Baptist, 388 NW2d 326, 330-31 (Mich App 1986).

s4 Even the authorizing statutes are often dedicated to detail. North Carolina's statute, for example, requires that nap-time mats "shall be of a waterproof, washable material at least two inches thick and shall be stored so that the floor side does not touch the sleeping side." NC Gen Stat § 110-91(1) (1989).

ss 40 Tex Admin Code Ann $§ 83.614$ et seq (Vernon 1980 \& Supp 1989). The Texas Child Care Licensing Act has generated considerable church-state litigation. See the series 
state interests behind each of the standards, it is also likely that several of the standards would fare poorly under the compelling interest test if applied to some church-sponsored day care providers. Imagine, for example, application of the community participation and community dress standards to those who wish for religious reasons to set themselves apart from the community. The standards promote a comparatively slight state interest, but would impose a substantial burden on religious freedom. In such cases, granting an administrative exemption would produce only a marginal sacrifice of the relevant state interest. The particular standard is only tangential to the state's fundamental interest, and it still applies to all other day care providers for whom the standard poses no religious burden.

Other standards at the core of the state's health and safety concerns represent significant state interests. Many states, for example, authorize the regulation of day care providers' disciplinary policies. ${ }^{56}$ In Dept. of Social Services v Emmanuel Baptist Preschool, ${ }^{57}$ the Emmanuel Baptist Preschool argued that the Michigan guidelines governing corporal punishment in day care facilities violated the biblical injunction, "spare the rod, spoil the child." 58 Emmanuel asserted that a sincere religious belief dictated that it literally use a rod-in modern terms, a ping pong paddle. ${ }^{59} \mathrm{~A}$ Michigan appellate court found that Emmanuel's religious exercise was burdened by a corporal punishment standard, but that the state's compelling interest in protecting its children justified the

of cases initiated by Reverend Lester Roloff, culminating in People's Baptist, 683 SW2d at 692. For an excellent discussion of the day care controversy in Texas, see Comment, Church-State Conflict under the Texas Child Care Licensing Act: A Ten-Year History, 39 Sw L J 1049 (1986).

s6 See, for example, Ohio Rev Code Ann \$ 5104.011(A)(3) (Page 1989); and Ill Ann Stat ch $23 \S 2217$ (a)(10) (Smith-Hurd 1988 \& Supp 1989).

s7 388 NW2d 326 (Mich App 1986). Over two years after it heard oral arguments and just as this Comment was going to press, the Michigan Supreme Court issued a memorandum opinion in this case. Dept. of Social Services v Emmanuel Baptist Preschool, No 79024 (April 9, 1990) ("Memorandum Opinion"). Four "concurring" opinions accompanied the memorandum opinion, leaving the Michigan Supreme Court deeply fractured over the outcome. This Comment was unable to take the various concurrences into account but does note the four holdings on which the court was able to agree.

so The administrative guidelines outlining the acceptable forms of spanking stipulated that "[n]o instrument is to be used to spank a child, except the open palm of the program director's or caregiver's hand." 1980 AACS, R 400.5107 as interpreted in Department of Social Services Instructional Memorandum No 80-09 (d), quoted in Emmanuel, 388 NW2d at 333. The biblical passage is found in Proverbs 13:24 (King James ver) ("He that spareth his rod hateth his son: but he that loveth him chaseneth him betimes.").

$388 \mathrm{NW} 2 \mathrm{~d}$ at 333. 
infringement. ${ }^{60}$ The state's interest is at a zenith when its regulation bears directly on the day care provider's basic physical and emotional treatment of the children under its care. ${ }^{61}$

Just as the strength of the state's interest varies from standard to standard, so does the extent to which any given standard burdens the religious exercise of church-sponsored day care providers. Thus, the Michigan court's finding that Emmanuel's religious exercise was burdened by a corporal punishment standard does not indicate whether other churches are also burdened by such standards. When a church challenged California's much more restrictive corporal punishment provision, the court found that the standard did not burden the church-sponsored day care provider's religious exercise. ${ }^{62}$

Because the relative strengths of state interest and religious burden depend upon the particular case, some states attempt to accommodate specific objections to licensing standards at the administrative level, when doing so will result in only a marginal sacrifice of the state's interest. Consider the following examples of administrative accommodation. ${ }^{63}$

6o Emmanuel, 388 NW2d at 334 . The court did not explicitly consider any less restrictive means through which the state could have secured its interest. But, as is often the case, the analysis may have been implicit. The state did not attempt to prohibit corporal punishment, but instead provided guidelines designed to allow flexibility for day care providers (especially those who felt they needed to administer corporal punishment), while retaining certain minimum protections for children.

-1 The Michigan Supreme Court's only point of unanimity was in upholding the state's corporal punishment provision. Emmanuel, Memorandum Opinion at 5.

${ }^{62}$ See North Valley Baptist Church v McMahon, 696 F Supp 518 (E D Cal 1988). 22 Cal Admin Code $\$ 101223(3)$ requires that children "be free from corporal or unusual punishment, infliction of pain, humiliation, intimidation, ridicule, coercion, threat, mental abuse, or other actions of a punitive nature." $696 \mathrm{~F}$ Supp at 520 . The court found that North Valley's objection to the standard was not founded on religious belief; most likely to his lawyer's dismay, North Valley's pastor had testified that the practice of spanking in the preschool was permitted, but not religiously required, by the church. Id at 532. Although it is hard to imagine that many specific objections that reach trial are resolved in this way, the case aptly demonstrates that the actual burden on religious exercise of any particular licensing standard is highly dependent on the specific beliefs of individual church-sponsored day care providers.

It may be that many of the church-sponsored day care providers' actual objections are general in nature, but that the futility of objecting on general grounds has led them to fashion specific objections in an attempt to have entire licensing schemes, as applied to church-sponsored providers, declared unconstitutional. In Emmanuel, many of the church's specific objections pointed to potential state intrusion into their religious affairs. In rejecting one specific objection, the court noted that Emmanuel seemed "to be voicing a general objection to governmental intrusion into church affairs through licensing" more than a specific grievance concerning an actual interference. 388 NW2d at 334-35.

63 Documented examples of administrative accommodations are, of course, somewhat limited. Neither the recipient nor the state has any reason to challenge them. Moreover, 
California's regulatory scheme provides no legislative exemptions for church-sponsored day care, and was challenged by a church-sponsored preschool in the North Valley case. One of North Valley's specific objections targeted the "religious services provision," which requires that each child "be free to attend religious services or activities of his/her choice and to have visits from the spiritual advisor of his/her choice." ${ }^{64}$ North Valley argued that the provision prevented it from conducting church services as part of its daily curriculum, and that the provision also required it to entertain visits from "spiritual advisors" of other churches. ${ }^{65}$ In response, the defendant administrative agency offered uncontested evidence that it had interpreted and administered the provision as a parental consent requirement; participating parents were informed in advance about the religious aspects of church-sponsored day care, and their consent to the particular provider constituted the "choice" as to religious services and counsel. The court found that the provision, "as so interpreted and enforced ... [did] not conflict with plaintiffs' religious beliefs." ${ }^{66}$ In effect, the implementing agency had granted an administrative exemption.

Similarly, a Michigan provision contested in Emmanuel requires that day care providers foster "a positive self-concept" among children. ${ }^{67}$ The church-sponsored preschool objected that the provision - which they deemed a codification of secular humanist values-violated the fundamentalist doctrine of the "innate depravity of mankind, which holds that all human beings are sinners in need of salvation." The preschool further argued that state inspectors could use the provision to prevent the further teaching of this fundamentalist doctrine. But a representative of the defendant agency testified that the provision "speaks to the way children are handled, i.e., whether they are belittled or demeaned by adults, or made to feel inferior to other children." 68 The court agreed with the state's assessment and declared it would not "invalidate a statutory scheme merely because it may be subject to an unconstitutional interpretation." ${ }^{\prime 9}$ In essence, the court found no

only a handful of states accommodate in this way. See Section IV.

64 22 Cal Admin Code $\S 101223(a)(5)$, quoted in North Valley, 696 F Supp at 520.

${ }^{65}$ North Valley, 696 F Supp at 533.

${ }^{68} \mathrm{Id}$.

${ }^{67} 1980$ AACS, R 400.5106(1)(c) (quoted in Emmanuel 388 NW2d at 332).

68 $388 \mathrm{NW} 2 \mathrm{~d}$ at 332 .

${ }^{69}$ Id at 333. The Michigan Supreme Court implicitly affirmed this holding when a majority upheld, with enumerated exceptions, application of the entire regulatory scheme to Emmanuel. Memorandum Opinion at 5-6. 
colorable objection to the statute because the state had granted an interpretive administrative exemption similar to California's treatment of its religious services provision..$^{70}$

Administrative consideration of specific objections is perhaps most effective in the hard cases, where the state's interest and the religious burden are both clearly established. Another specific objection in Emmanuel contested a Michigan provision which established minimum educational requirements for day care program directors, including a minimum of sixty completed semester hours at an accredited college or university. ${ }^{71}$ Emmanuel objected that the requirement prevented it from choosing a director who possessed compatible religious beliefs, ${ }^{72}$ since most of the church's preschool directors were hired from fundamentalist Christian colleges, which typically object to accreditation. ${ }^{73}$ Though the lower court held that the educational requirements were an unconstitutional violation of Emmanuel's free exercise, the appellate court reversed and held for the state, relying on a special administrative exemption that the state granted to church-sponsored day care providers like Emmanuel. The exemption freed license applicants from any administrative rule if there was clear and convincing evidence of compliance with the intent of the rule. ${ }^{74}$ In this way, the state had presented church-sponsored day care providers with an opportunity to engage in their own form of "least restrictive means" evaluation. They could exempt themselves from administrative regulation by assuring the state that its compelling interest was being served.

\section{Challenges Under the Establishment Clause}

Given the extensive array of objections to state regulation and the accompanying potential for significant Free Exercise Clause

70 The holding was also at least partially due to the strength of the state's interest in preventing emotional abuse. Id.

71980 AACS, R 400.5104(2) (cited in Emmanuel, 388 NW2d at 331).

$32388 \mathrm{NW} 2 \mathrm{~d}$ at 331 .

${ }^{3}$ Id. For a general discussion of the controversy over accreditation and the religion clauses, see Matthew B. Durrant, Accrediting Church-Related Schools: A First Amendment Analysis, 38 Ark L Rev 598 (1985).

7t 1980 AACS, R 400.5118 (cited in Emmanuel, $388 \mathrm{NW} 2 \mathrm{~d}$ at 331). There was also evidence that the Department of Social Services had developed a special set of criteria for measuring the competence of graduates from church-affliated colleges. This administrative exemption can be seen as an attempt to use the least restrictive means concept to achieve Michigan's interest in quality care for its young children. The Michigan Supreme Court specifically forbade the state from "enforc[ing] the accreditation aspects of the program director qualification rule. ..." Memorandum Opinion at 6. 
controversy, it should not be surprising that some states seek to avert church-state conflicts by exempting church-sponsored day care providers from certain day care standards. Unfortunately, these exemptions raise their own set of constitutional concerns. This section addresses the Establishment Clause challenges to state involvement in day care.

\section{A. The Lemon Test}

The Supreme Court, admitting it could but "dimly perceive the lines of demarcation in this extraordinarily sensitive area of constitutional law," announced in Lemon $v$ Kurtzman a threeprong test to measure the constitutional validity of state actions under the Establishment Clause: "First, the statute must have a secular legislative purpose; second, its principal or primary effect must be one that neither advances nor inhibits religion ... .; finally, the statute must not foster 'an excessive government entanglement with religion." "75

The Lemon test has engendered volumes of interpretation and two decades of debate, but has endured as the framework for most of the Supreme Court's subsequent Establishment Clause decisions. ${ }^{76}$ The three-part analysis can be summarized briefly as follows. The first prong-secular purpose-reflects the expectation that legislation be intent-neutral. State action should not be aimed at benefiting a religion or all religions. Alternatively formulated, the class that is the object of the legislation must have a common denominator broader than religion. ${ }^{77}$ The second prong-primary effect-means that state action should neither "encourage[] nor discourage[] participation in religious life."78 This is the expectation that legislation be essentially effect-neutral. ${ }^{79}$ The third

75403 US 602, 612-13 (1971), quoting Walz v Tax Commission, 397 US 664, 674 (1970).

${ }^{76}$ The Court has noted that the Lemon analysis "provides 'no more than [a] helpful signpos[t]' in dealing with Establishment Clause challenges." Mueller $v$ Allen, 463 US 388, 394 (1983), citing Hunt v McNair, 413 US 734, 741 (1973). The Court avoided the Lemon analysis altogether in Marsh $v$ Chambers, 463 US 783 (1983) (upholding challenge to legislature's paid chaplain), opting for a historical analysis instead. But the Court continued to use Lemon analysis in the late 1980s. See Bowen $v$ Kendrick, 487 US 589 (1988); Texas Monthly, Inc. v Bullock, 109 S Ct 890 (1989); Hernandez $v$ Commissioner of Internal Revenue, 109 S Ct 2136 (1989); and County of Allegheny v ACLU, 109 S Ct 3086 (1989).

77 Walz, 397 US at 696 (Harlan concurring). The exception is presented by exemptions, in which the class, by definition, is religious in nature. See note 127.

${ }_{78}$ Walz, 397 US at 697 (Harlan concurring). Before its incorporation into the Lemon formula, this aspect was labeled "voluntarism."

79 The Court often speaks of a "benevolent" neutrality in this regard. Walz, 397 US at 669. Here, too, the Court employs a common denominator analysis. A religious organization 
prong-excessive entanglement-is meant to prevent the deleterious commingling of church and state functions and activities. ${ }^{80}$ In practice, the entanglement prong has proved notoriously amorphous.

There are two general categories of Establishment Clause challenges to state regulation of day care, each of which stands in tension with the other. State decisions to exempt church-sponsored day care providers from licensing standards may be challenged as unduly advancing religion, while state decisions to impose statutory or administrative standards on church-sponsored day care providers may be challenged as creating excessive entanglement. ${ }^{81}$

\section{B. Challenges to Religious Exemptions}

Secular day care providers and others often assert that exempting church-sponsored day care providers from licensing requirements has the effect of impermissibly advancing religion. The critical question is how far beyond the requirements of the Free Exercise Clause the state may permissibly accommodate churchsponsored day care providers before implicating the prohibitions of the Establishment Clause. Although the Supreme Court has never considered the day care issue specifically, it recently rejected an Establishment Clause challenge to a religious exemption in another context. That decision, Corporation of Presiding Bishop v Amos, ${ }^{82}$ has affected the day care exemption inquiry in lower courts and contains important implications for the interaction of the religion clauses. This section therefore first considers the Court's jurisprudence on religious accommodations, in particular the Amos decision, and then explores the application of these cases to day care exemptions.

may benefit from legislation only as a member of a broader category of recipients, such as non-profit organizations. See Texas Monthly, Inc., $109 \mathrm{~S} \mathrm{Ct}$ at 897-98 (striking down Texas sales tax exemption for religious periodicals as lacking "sufficient breadth").

so Lemon discussed two varieties of entanglement: administrative oversight and political divisiveness. 403 US at 621-22. Justices White and Rehnquist, dissenting in Roemer, 426 US at 767 (1976), and Justice O'Connor, dissenting in Aguilar v Felton, 473 US 402, 421 (1985), take issue with this prong of the test, suggesting it only reconsiders intent and effect.

${ }^{81}$ Needless to say, the state is damned if it does and damned if it doesn't in developing standards for church-sponsored day care. It is hard to imagine that the Establishment Clause supports these conflicting propositions.

${ }^{82} 483$ US 327 (1987). 
1. Supreme Court accommodation jurisprudence and Amos.

The Supreme Court's jurisprudence provides the following constitutional guidelines concerning accommodation: sometimes it is required, ${ }^{83}$ sometimes it is permitted ${ }^{84}$ and sometimes it is prohibited. ${ }^{85}$ The confusion arises because challenged accommodations are analyzed under the three-part Lemon test. ${ }^{86}$ Neither the purpose nor effect of accommodation is neutral toward religion. In Corporation of Presiding Bishop v Amos, ${ }^{87}$ the Court addressed the confusion and explicitly considered Lemon's application to accommodations, particularly religious exemptions.

At issue in Amos was $\S 702$ of the Civil Rights Act of $1964,{ }^{88}$ which exempts religious organizations from the ban on religious discrimination imposed by Title VII of the Act. ${ }^{89}$ The plaintiff/respondent was an employee of a Salt Lake City non-profit gymnasium that was owned and operated by the petitioner corporation, an affiliate of the Mormon Church (Church of Jesus Christ of Latter-day Saints). He was fired when he no longer qualified as a member of the church in good standing, and brought suit under Title VII. The church claimed exemption under $\S 702$. The District Court ruled for respondent, holding that $\S 702$ violated the second prong of the Lemon test because it had the primary effect of advancing religion. On direct appeal, the Supreme Court reversed

${ }^{83}$ See Thomas $v$ Review Board, 450 US 707, 719-20 (1981); Wisconsin v Yoder, 406 US 205, 234-35 n 22; and Sherbert v Verner, 374 US 398, 409 (1963). Any result other than requiring accommodation would create an irreconcilable contradiction between the clauses.

8* See Zorach v Clauson, 343 US 306, 312-15 (1952) (upholding release time program for public school students to allow them to attend off-campus religious classes). The Court has found "room for play in the joints" between the clauses that allows legislatures leeway in choosing accommodations that are neither required by the Free Exercise Clause nor prohibited by the Establishment Clause. Walz, 397 US at 669-73; and Michael W. McConnell, Accommodation of Religion, 1985 S Ct Rev 1, 29-34.

${ }^{85}$ See Wallace $v$ Jaffree, 472 US 38 (1985) (Alabama's moment of silence for voluntary prayer in public schools violated Lemon's secular purpose prong); and Estate of Thornton $v$ Caldor, 472 US 703 (1985) (absolute right not to work on a designated sabbath violated Lemon's primary effect prong).

${ }^{86}$ Numerous courts and commentators have pointed to the analytical anomalies of assessing the constitutionality of accommodations under the Lemon rubric. See, for example, Wallace, 472 US at 82-83 (O'Connor concurring); and McConnell, $1985 \mathrm{~S}$ Ct Rev at 44, 5859 (cited in note 85 ).

87 483 US 327 (1987).

88 As amended, 42 USC § 2000e-1 (1982).

80 Section 702, in pertinent part, states: "This title shall not apply to . . a religious corporation, association, educational institution, or society with respect to the employment of individuals of a particular religion to perform work connected with the carrying on by such corporation, association, educational institution, or society of its activities." 42 USC § 2000 e-1. 
and discussed each part of the Lemon test as it applies to religious exemptions.

With regard to secular purpose, the Court declared that "it is a permissible legislative purpose to alleviate significant governmental interference with the ability of religious organizations to define and carry out their religious missions." Exemptions alleviate the "significant burden on a religious organization . . . to predict which of its activities a secular court will consider religious."91 In essence, the Court relaxed secular purpose scrutiny in reviewing challenged exemptions.

In discussing primary effect, the Court explained that the kind of government action the founders meant to proscribe was "sponsorship, financial support, and active involvement" ${ }^{\text {"g2 }}$ in religious matters. Thus, "[a] law is not unconstitutional simply because it allows churches to advance religion, which is their very purpose. For a law to have forbidden 'effects,' the Government itself must have advanced religion through its own activities and influence."93 Finally, the Court asserted that because a religious exemption fully alleviates the "intrusive inquiry into religious belief," it is quite effective at avoiding excessive entanglement. ${ }^{\text {94 }}$

\section{The day care cases.}

The application of Amos exemption analysis to day care cases has the potential to profoundly alter courts' approaches to Establishment Clause challenges of religious exemptions for churchsponsored day care providers. The effect of Amos is best demonstrated by first reviewing the day care cases that pre-date it, and then turning to the emerging case law that injects Amos's principles into day care exemption analysis.

a. Pre-Amos cases. Arkansas Day Care Ass'n, Inc, v Clin$t{ }^{95}$ provided a federal district court the unique opportunity to rule on alternate versions of religious exemptions in the same controversy. ${ }^{96}$ Arkansas had both a narrow registration scheme ${ }^{97}$ and a

so Amos, 483 US at 335.

91 Id at 336.

92 Id at 337 , quoting Walz, 397 US at 668.

${ }^{93}$ Amos, 483 US at 337 (emphasis in original).

or Id at 339.

${ }^{95} 577$ F Supp 388 (E D Ark 1983).

${ }^{96}$ Over several years, the Arkansas legislature established a series of religious exemptions to the state's Child Care Facility Licensing Act. Because the legislature failed to repeal several of the provisions, a dual system of exemptions for church-sponsored day care providers developed. See Arkansas Day Care, 577 F Supp at 390-94. 
rather broad blanket religious exemption in place simultaneously; day care providers were subject to one or the other according to their date of establishment. ${ }^{88}$ The court applied Lemon analysis to uphold the registration scheme as "a reasonable accommodation to the religious beliefs recognized by the legislature," date the blanket exemption as an "over-accommodation." 100 While the ruling rested partially on the state's seemingly arbitrary application of separate sets of exemptions, ${ }^{101}$ the court also advanced several important distinctions between the two approaches to exempting church-sponsored day care providers.

The court found that the registration scheme did not bestow "any significant or substantial advantage, economic or otherwise"102 on church-sponsored day care providers. And it approved of the registration scheme's purpose of "encouraging the establishment of day care centers which provide safe and wholesome environments." tions because they failed to adequately protect the state's interests in regulating day care. ${ }^{104}$

In Forest Hills Early Learning Center $v$ Lukhard, ${ }^{105}$ the Fourth Circuit invalidated an expansive religious exemption for church-sponsored day care providers. At issue was Virginia's version of registration, under which church-sponsored day care providers were required only to register, fulfill minimum notice and

${ }_{97}$ Enacted in 1983, Act 245, Ark Stat Ann $\$ \S 20-78-209$ (1987), exempts church-sponsored day care providers from licensing requirement, but in most other respects requires them to conform to the same regulations as secular providers. Arkansas Day Care, $577 \mathrm{~F}$ Supp at $392-93$.

98 Id at 394. The broader version, enacted in 1981 as Act 518, Ark Stat Ann $\$ 83-918$, exempted church-sponsored day care providers from most regulations, except for local fire, health, and safety standards. It prohibited inspection except in cases of suspected child abuse. Arkansas Day Care, 577 F Supp at 393.

99 Arkansas Day Care, 577 F Supp at 396.

100 Id at 398.

101 Id.

102 Id at 396.

${ }^{103}$ Id at 397. Although the court's language can be construed to say that the valid purpose was that of encouraging more day care, which in general meets an important social need, the language comes dangerously close to an endorsement of the particular virtues of church-sponsored day care. The court's emphasis on primary effect and its more casual approach to secular purpose are representative of accommodation exemption analysis even before Amos. So long as accommodations did not have the primary effect of advancing church-sponsored care, courts were willing to fudge on secular purpose.

104 Id at 398.

105728 F2d 230 (4th Cir 1984). 
disclosure requirements, and abide by the already applicable local fire, health and safety codes. ${ }^{106}$

The Fourth Circuit invalidated the Virginia exemption as "overbroad in relation to the secular legislative purpose claimed for it." 107 Virginia had asserted that the secular purpose was the accommodation of religious day care providers' free exercise rights. While the court acknowledged the potential validity of such a claim, ${ }^{108}$ it found insufficient evidence of possible infringement on religious exercise to justify the breadth of the exemption. ${ }^{109}$ The court's unwillingness to relax its scrutiny of secular purpose seemed clearly related to the ambitious breadth of the challenged exemption. ${ }^{110}$

The court remanded the case for further consideration, suggesting that the affected class of church-sponsored day care providers (none of which was involved in the litigation at that point) intervene and present its free exercise case to the district court. ${ }^{111}$ The case eventually returned to the Fourth Circuit, complete with the affected class of church-sponsored day care providers, ${ }^{112}$ but in the meantime the Supreme Court had issued its holding in Amos.

b. Post-Amos cases. The Fourth Circuit's reexamination of the Forest Hills case is a particularly appropriate example of the effect Amos has had on the Lemon inquiry regarding exemptions for church-sponsored day care providers. Taking its cue from Amos, the Fourth Circuit this time ruled that it was "a permissible

108 The only other applicable substantive requirement was a set of minimum staff-child ratios. Church-sponsored providers were also exempt from any enforcement mechanisms except, of course, the local fire, health, and safety authorities. Va Code $\$ \S 63.1-196.3$ (1950). See the discussion in Forest Hills, 728 F2d at 235-37.

${ }^{107}$ Forest Hills, 728 F2d at 244.

${ }_{108}$ Id at 241.

109 "Certainly it cannot be the case that merely by asserting such a legislative purpose in litigation the state is entitled to have its legislature's accommodation to assumed free exercise rights confirmed by the courts without any judicial inquiry into the validity of the assumption. The requirements of judicial deference to legislative recognition of constitutional rights cannot be thought to run that far." Forest Hills, 728 F2d at 240. In fact, the court cited evidence suggesting that the church-sponsored day care providers did not object to many of the specific objections from which they were exempted. Id at 243-44.

110 Id.

111 Id at 245. See also Forest Hills Early Learning Center v Lukhard, 789 F2d 295 (4th Cir 1986) (a second hearing resulting in another remand to allow intervention). Without the presence of affected church-sponsored providers, consider the irony of the resulting litigation positions. The state, having established a religious exemption as an accommodation, is left to defend the validity of the free exercise claims, instead of defending any compelling interest it had in the regulation of day care.

112 Forest Hills Early Learning Center $v$ Grace Baptist Church, 846 F2d 260 (4th Cir 1988), cert denied, $109 \mathrm{~S} \mathrm{Ct} 837$ (1989). 
and sufficient legislative purpose to alleviate significant governmental interference with the ability of religious organizations to define and carry out their religious missions,"113 and upheld Virginia's broad exemption. The court explained that the kinds of "burdens" that were of concern in Amos were evident in this case:

Absent the exemption, some church leaders would immediately be forced to violate their convictions against submitting aspects of their ministries to state licensing, or face legal action by the state. This would be an unseemly clash of church and state which the legislature might well wish to avoid. Our earlier opinion shifted to the churches the initial burden of producing evidence "to establish the extent, if any, of their free exercise rights in the exempted activities." As a result, they have already been put to the difficult and intrusive burden of attempting to persuade a secular court of the sincerity and centrality of the beliefs they consider threatened by government licensing. ${ }^{114}$

As the court suggests, Amos eliminates Lemon's first prong from the exemption inquiry, so that the government no longer need demonstrate that a free exercise burden passes the compelling interest test in order to survive an Establishment Clause inquiry. Legislatures need not relate their exemptions to grounds any more specific than the general accommodation of free exercise. ${ }^{115}$

\section{Accommodating Amos: The danger of misapplication.}

But does Amos fit the day care context? The best justification for the Fourth Circuit's turnabout is deference to the state legislature. Amos holds that it is legitimate for legislatures to be concerned about potential free exercise infringements, and on that basis alone to pass exemptions to prevent them. Under this view, it is not the role of the judiciary to second-guess a legislative decision to accommodate by reassessing the free exercise claims. The only

113 Forest Hills, 846 F2d at 263, quoting Amos, 483 US at 335 .

114 Forest Hills, 846 F2d at 263 (citation omitted).

11 The Supreme Court of Illinois has also relied on Amos's formulation of the Lemon test to uphold Illinois's relatively narrow religious exemption. Pre-School Owners Ass'n v Department of Family Services, 518 NE2d 1018, 1024-25 (Ill 1988), upholding Ill Ann Stat ch $23 \S 2212.09$ (i) (Smith-Hurd 1988 \& Supp 1989). The statute exempts church-sponsored facilities that care for children over three years of age only if the providers are tax-exempt, receive no governmental aid, operate primarily to provide religious instruction, meet fire, health, and safety codes, and are operated in conjunction with a non-profit, religious elementary school. 
real question for judicial determination is whether the exemption is an establishment. At the margins-when exemptions go too far and are establishments, or when licensure requirements impose undue burdens on free exercise-the Constitution protects religious freedom. But this leaves considerable maneuverability and discretion for the legislatures in their attempts to both license and accommodate. ${ }^{116}$

Prudence, however, still requires careful consideration of how Amos should be applied in the day care context. Enthusiasm for the secular purpose solution does not require abandoning scrutiny of primary effect. Yet this is the present danger. When courts prior to Amos relaxed the secular purpose prong, as in Arkansas Day Care and Forest Hills, they accorded greater weight to the primary effect prong of the inquiry. ${ }^{117}$ Given its relaxation of the secular purpose prong, the Amos Court might have been expected to caution against the possible impermissible effects of broad accommodations. But the Court described the primary effect inquiry with surprisingly broad, accommodationist language. A careful look at the Court's decision in Amos, however, reveals that it thoroughly considered primary effect and explicitly found "no persuasive evidence ... that the Church's ability to propagate its religious doctrine through the Gymnasium is any greater now than it was prior to the passage [of the exemption] ...."118 The employment discrimination exemption granted to the church-sponsored gymnasium provided the Church no economic or other secular advantage. In fact, the exemption was actually an economic disadvantage in that the gymnasium used it to limit its employee hiring pool. There is simply no economic advantage in being an employer who hires only Mormons.

The nature of regulation and exemptions is dramatically different in the day care setting. State licensing standards almost in-

${ }^{116}$ In a dissenting opinion in Sherbert $v$ Verner, 374 US 398, 418 (1963), Justice Harlan, joined by Justice White, defended the notion of state flexibility. Under this view, a state could "permit a legislative judgment accommodating an unemployment compensation law to the exercise of religious beliefs such as appellant's." Id at 423 . But the state is also not "compelled to carve out an exception to its general rule of eligibility in the present case. Those situations in which the Constitution may require special treatment on account of religion are ... few and far between." Id.

${ }^{117}$ In Arkansas Day Care, the court seemed willing to fudge the secular purpose inquiry because the challenged registration scheme was narrow and provided no economic or other advantage to the church-sponsored day care providers it affected. $577 \mathrm{~F}$ Supp at 396. Compare Forest Hills, where the court placed emphasis on the breadth of the challenged exemptions in refusing to relax the scrutiny of secular purpose. $728 \mathrm{~F} 2 \mathrm{~d}$ at $243-44$.

${ }_{118}$ Amos, 483 US at 337. 
variably limit and burden day care providers, so that exemptions from licensing standards do provide an economic advantage. If a church-sponsored day care provider, for example, can only hire its program director from an accredited college or university, it will have to pay her more than if it could choose from the larger employee pool. This economic burden often accompanies even minor licensing requirements. And the more exemptions, the bigger the advantage. Thus, exempting churches from day care licensing requirements advantages them in a way that exempting them from religious discrimination statutes does not.

In short, acknowledging that accommodation of free exercise is an appropriate secular legislative purpose should not also obviate an inquiry into the possible effects of the accommodation. But this is exactly what the Fourth Circuit did in its reexamination of Forest Hills after Amos. The pre-Amos Forest Hills court never needed to reach the effects inquiry, since it based its decision on secular purpose. But on reexamination, the court failed to carefully scrutinize effects only because it misapplied Amos. It merely cited, without more, Amos's conclusions about the primary effect of granting an exemption from Title VII to a Mormon-sponsored gymnasium.

An appropriate Establishment Clause inquiry into exemptions for church-sponsored day care providers requires courts to examine the effect of the particular exemption, as the Supreme Court did in Amos. In fact, in the day care context it is often likely that the reviewing court will have to consider the effects of an exemption on a particular day care provider. As discussed earlier, the bulk of rule development, monitoring, and enforcement, including exemptions, is often relegated to administrative agencies. In many cases the religious exemption will have been granted by the administrative agency to a specific applicant with a specific objection.

\section{Entanglement Challenges}

The second category of Establishment Clause challenges to state regulation of day care focuses on a state's decision not to exempt-in other words, the decision to impose statutory or administrative standards on church-sponsored day care providers. The question is whether such a regulation violates Lemon's third prong by creating excessive entanglement. Here it is useful to consider Lemon in context. Lemon involved a Rhode Island statute that provided salary supplements to teachers of secular subjects in nonpublic elementary schools, and a similar Pennsylvania provision that reimbursed non-public schools for teaching specified secular 
subjects. ${ }^{119}$ As in most of the parochial aid cases, the recipient nonpublic schools were overwhelmingly sectarian. The Court held that both statutes violated the entanglement prong of the test because they would require an impermissible degree of state surveillance in order to assure that the funded courses were sufficiently secular to satisfy the effects prong of the test. ${ }^{120}$

There are three reasons to reject entanglement challenges to regulations unaccompanied by subsidies. First, invoking the Establishment Clause to invalidate regulation confuses the textual division of labor between the religion clauses. ${ }^{121}$ While it is useful to conceive of both the religion clauses as seeking "to mark boundaries to avoid excessive entanglement," 122 establishment entanglement is concerned-as was Lemon-with excessive surveillance in the unique context of government sponsorship or aid that should not reach church-sponsored institutions qua churches. But plaintiff church-sponsored day care providers are describing free exercise entanglement: excessive state interference with their religious practices. ${ }^{123}$

This distinction undercuts Amos's assertion that granting religious exemptions prevents entanglement-the assertion is actually nothing more than an observation that granting religious exemptions prevents free exercise entanglement, which is not particularly surprising or insightful. And contrary to Amos's implication, when a state decides not to exempt (aid) a church-sponsored institution, no threat of establishment entanglement is present. The state has no reason to delve into the separability of the sectarian and secular aspects of the regulated provider. ${ }^{124}$

Second, the use of Lemon's entanglement prong to invalidate state regulatory requirements imposed upon church-sponsored day care providers is difficult to reconcile with Lemon's effect prong because it results in "unequal state treatment" of the religious and

119 Lemon, 403 US at 606-07.

120 Id at 614.

" ${ }^{221}$ Entanglement challenges were rejected for this very reason in both Emmanuel, 388 NW2d at 335, and People's Baptist, 683 SW2d at 694-95.

122 Walz, 397 US at 670 . When the state either advances or infringes upon religious practice, its involvement with religion has become excessive.

${ }^{123}$ This assertion of Free Exercise Clause interests under the rubric of the Establishment Clause has been called "negative establishment." See Forest Hills, 728 F2d at 238 n 6 (negative establishment "involve[s] questions ... that we think are wholly subsumed within the more direct question whether and to what extent free exercise rights of the sectarian operators may have been burdened. ...").

124 People's Baptist, 683 SW2d at 695. 
non-religious day care providers. ${ }^{125}$ The irony of this interplay between the "Scylla and Charybdis of 'effect' and 'entanglement" "126 is more an indictment of the Lemon test's internal inconsistency than the entanglement prong itself. But the conflict between Lemon's second and third prongs is more acute when the test is used to assess the constitutionality of exemptions. ${ }^{\mathbf{2 7}}$

Finally, to grant the Establishment Clause entanglement objection without considering the free exercise analysis would be tantamount to allowing church-sponsored organizations to "occupy the field" by entering an otherwise secular, regulated activity and then protesting the presence of regulation, not any actual religious burden resulting from the regulation. In our highly regulated welfare state, the mere coexistence of state regulation and church participation in a given area should not govern First Amendment analysis.

\section{Mitigating Tension Between the Clauses: A Proposed Approach to State Regulation}

This Comment began by noting the difficulties of satisfying the demands of both religion clauses when a church participates in an otherwise secular, regulated service. The first problem is that state regulations may impose substantial burdens on churches' religious freedom. To minimize free exercise burdens, states often grant exemptions, either at the legislative or administrative level.

The second problem is that these efforts to accommodate free exercise, if cast too broadly, may result in an impermissible establishment of religion. In Amos, the Court recognized that granting religious exemptions is consistent with Lemon's secular purpose requirement; the Court will defer to legislatures within the zone between the requirements of the two religion clauses. But Amos should not be read as relaxing the primary effect inquiry for ex-

${ }^{125}$ This unequal treatment impinges on Lemon's second prong. People's Baptist, 683 SW2d at 695 .

${ }^{126}$ Committee for Public Education \& Religious Liberty $v$ Nyquist, 413 US 756, 788 (1973).

${ }^{127}$ In her concurring opinion in Wallace v Jaffree, Justice O'Connor noted that "[o]n the one hand, a rigid application of the Lemon test would invalidate legislation exempting religious observers from generally applicable government obligations. By definition, such legislation has a religious purpose and effect in promoting the free exercise of religion. On the other hand, judicial deference to all legislation that purports to facilitate the free exercise of religion would completely vitiate the Establishment Clause. Any statute pertaining to religion can be viewed as an 'accommodation' of free exercise rights." 472 US 38, 81-82 (1985). 
emptions: a solution which solves the tension between the clauses by eviscerating the Establishment Clause is no solution at all. A better solution is to make sure that the accommodation net is not cast too broadly. This requires a more closely tailored approach to the free exercise inquiry.

\section{A. The Ideal State Statute}

The ideal state approach ${ }^{128}$ to the regulation of day care providers would entail a dual regulatory scheme of licensure and registration. The registration scheme would exempt qualified churchsponsored day care providers from the set of foreseeably objectionable requirements that are only peripheral to the state's compelling interest in protecting children, such as the need to obtain a "license" and post it on the premises, the assessment of fees, and any regulation of curriculum content or program material. Churchsponsored day care providers would qualify for registration by their tax-exempt church status; church-housed but independently operated programs that are not themselves tax-exempt church organizations would not qualify.

Church-sponsored day care providers would still be subject-just like secular day care providers-to the full complement of health and safety standards, such as staff-child ratios, disciplinary policies, and traditional enforcement mechanisms, with the following critical exception: the registration scheme would provide a mechanism for church-sponsored day care providers to apply for and obtain administrative exemptions from any specific provision, including enforcement procedures. The church-sponsored day care provider seeking specific exemptions would be required in each case to accompany its request with an affidavit by the sponsoring church's spiritual leader affirming the religious nature of its objections. The provider would also be required to submit a brief explanation of how it proposes to satisfy the intent of the relevant regulation.

The affidavits would be considered proof per se of sincere religious objection. The critical part of the request for exemption would be the church-sponsored day care provider's assurance of compliance in spirit. The authorizing statute would encourage the administrative agency to work together with church-sponsored

228 For another suggested approach to state regulation of "social service ministries," see Carl H. Esbeck, State Regulation of Social Services Ministries of Religious Organizations, 16 Valp U L Rev 1, 54 (1981). 
providers to develop solutions. In this way, the scheme would provide a thumb-on-the-scales for granting specific exemptions to those church-sponsored day care providers with religious objections. It would include a system of appeal and review for rejected applications, but the statutory and administrative goal would be to accommodate the specific objections of church-sponsored providers to the fullest extent compatible with the protection of children's health and safety.

Finally, church-sponsored day care providers exempted from specific provisions would be subject to notice and disclosure requirements to assure informed parental consent to their individual practices and policies.

\section{B. The Virtues of Administrative Accommodation}

This system of administrative accommodation strikes a balance between the demands of the religion clauses. The Free Exercise Clause requires the state to serve its compelling interest in childrens' health, safety, and well-being through means that least restrict church-sponsored day care providers' religious expression. The Establishment Clause prevents the state from granting church-sponsored day care providers a significant competitive advantage over secular day care providers. The state must neither maintain unswerving control, nor allow unbridled freedom; it must choose its exemptions carefully.

The legislature is not suited to this task. Recall the complexity of weighing free exercise objections. First, there are an almost infinite number of possible regulations and religious objections. Particular state legislatures do not know which regulations will be promulgated, or what objections will be raised against them. Second, the relative weight of church and state interests, and the marginal sacrifice to each, will vary from situation to situation. But the legislature is forced to consider interests in a vacuum, void of critical context. An administrative agency is in a far better position to conduct a least restrictive means inquiry informed by the circumstances of individual situations.

The other option is to grant blanket exemptions for the church-sponsored day care providers. But, like general objections, general exemptions are untenable because compelling state interests will necessarily be sacrificed, even when there is no religious objection. ${ }^{129}$ Moreover, considering the wide range of specific li-

${ }^{128}$ Imagine the youngster whose parents place him, because of his family's sincere reli- 
censing requirements that a blanket religious exemption would necessarily vitiate, impermissible advancement of the religious over the secular day care provider is almost inevitable.

Administrative accommodation may be criticized as creating excessive entanglement. But the entanglement criticism confuses the two versions of entanglement present in the religion clauses. As explained above in section III, Establishment Clause entanglement concerns the deleterious consequences resulting from government aid to religion. The entanglement at issue here is that prohibited by the Free Exercise Clause-the entanglement that represents an undue burden on religious exercise. This is precisely the burden that administrative accommodation of free exercise, by definition, is meant to alleviate. The compelling interest test's least restrictive means requirement is the free exercise version of entanglement. When the state searches for the least restrictive system of regulation that still satisfies its compelling interest in the health, safety, and well-being of its children, it should simultaneously find the least entangling system.

\section{CoNCLUSION}

Courts and commentators have often described the existence of room for play between the religion clauses. This Comment asserts that in the day care context there is less room than some have supposed. Contrary to the Fourth Circuit's interpretation of Amos, state efforts to accommodate should be well-tailored to the actual objections of individual church-sponsored day care providers and cognizant of establishment concerns. Particularly in this context, where church and state ostensibly share a concern for children's well-being, it is appropriate for both to work together towards reasonable regulations that protect children and impose the least possible intrusion on religious exercise.

gious beliefs, in a church-sponsored day care center. The state legislature has granted a blanket exemption for all such church-sponsored centers from all of the relevant licensing requirements, except the fire, building, and sanitation codes. Thus, at his day care center there is neither monitoring nor enforcement of the otherwise applicable corporal punishment provisions. If he is severely beaten, then, in effect, he is punished for exercising religious choice. In fact, all of the children in the state who exercise a religious choice to attend a church-sponsored day care center are deprived of their health and safety by having to attend sub-standard day care facilities. And the risk is largely unnecessary because the vast majority of the exempted providers do not actually have religious qualms about the regulations. See note 20 . 
